УДК 316.472 .3

DOI https://doi.org/10.26661/2310-4368/2020-2-24

\title{
СІМЕЙНА ВЗАСМОДІЯ В РАКУРСІ РОЗВИТКУ ГРОМАДЯНСЬКОЇ КОМПЕТЕНТНОСТІ МОЛОДІ: ПОКАЗНИКИ ДОСЛІДЖЕННЯ
}

\author{
Скнар О. М. \\ кандидат психологічних наук, старший науковий співробітник, \\ старший науковий співробітник лабораторії психологї політичної поведінки молоді \\ Інститут соиіальної та політичної психології \\ Національної академії педагогічних наук України \\ вул. Андрївська, 15, Київ, Украӥна \\ orcid.org/0000-0001-7883-680X \\ sknar_o@ukr.net
}

Ключові слова: громадянська компетентність, взаємодія в сім' $\dddot{\imath}$, середовище сімейнӧ̈ взаємодії, показники дослідження, кордони, ієрархія, гнучкість, згуртованість.
Стаття присвячена теоретичному обгрунтуванню та окресленню показників дослідження взаємодії у сім'ї як чинника розвитку громадянської компетентності особистості, що зростає. Актуальним завданням для сучасної науки визначено дослідження соціально-психологічних чинників, що сприяють формуванню готовності молодих людей до компетентної громадянської поведінки, завдяки якій вони зможуть продуктивно діяти в суспільно-політичному просторі, приймати самостійні рішення й відповідати за них, колективно вирішувати спільні проблеми, зважаючи на соціальні наслідки своїх дій й довгострокову користь для суспільства тощо. Обгрунтовано доцільність дослідження особливостей впливу взаємодії в сім’ї (в підсистемі «батьки - діти») на подальший розвиток громадянської компетентності молоді. Виходимо з розуміння ролі сім'ї як такої, що визначає не лише розвиток дитини, а й врешті-решт - всього суспільства. Сімейне середовище розглянуто як майданчик для засвоєння настанов та правил i норм, опанування навичок взаємодії, яке може сприяти / перешкоджати розвитку компетентності дитини, а в подальшому - компетентної поведінки громадянина в суспільстві. Визначено показники для оцінювання середовища сімейної взаємодії. Конкретизовано індикатори для кожного показника, за якими буде оцінюватись розвивальний потенціал сімейної взаємодії: зовнішні і внутрішні кордони (наявність і визнання норм і правил взаємодії, готовність їх дотримуватись; відповідальне ставлення до власних обов'язків; право на власну думку; право на участь у прийнятті рішень; готовність добровільно об'єднуватись з іншими заради спільної мети); ієрархія (баланс домінуванняпідпорядкування у взаємодії; здатність визнавати авторитет влади; контроль прийняття рішень; здатність підпорядковувати власні наміри, дії спільним інтересам); гнучкість норм і правил (змінюваність правил взаємодії при зміні ситуації у сім’і (спільноті); відкритість переговорів щодо норм і правил; можливість зміни ролей в разі необхідності); згуртованість (образ «Ми», здатність до емпатії, співпереживання, спів-причетності та розуміння потреб й інтересів Інших, баланс автономності - емоційної зв'язаності). 


\title{
FAMILY INTERACTION IN THE PERSPECTIVE OF THE DEVELOPMENT OF CIVIL COMPETENCE OF YOUTH: RESEARCH INDICATORS
}

\author{
Sknar O. M. \\ Ph.D., Senior Researcher, \\ Senior Researcher at the Laboratory of Psychology of Political Behavior of Youth \\ Institute for Social and Political Psychology of the National Academy \\ of Educational Sciences of Ukraine \\ Andriivska str., 15, Kyiv, Ukraine \\ orcid.org/0000-0001-7883-680X \\ sknaro@ukr.net
}

Key words: civic competence, family interaction, family interaction environment, research indicators, boundaries, hierarchy, flexibility, cohesion.
The article is devoted to the theoretical substantiation and description of indicators of the study of interaction in the family as a factor of the development of the growing individual civic competence. It is an urgent task for modern science to study the socio-psychological factors that contribute to the formation of young people's readiness for competent civic behavior, which facilitates their productive activities in the socio-political environment. This includes independent decisionmaking and responsibly for the decisions, collective solution of common problems, consideration of social consequences of their actions and long-term benefits for the society, etc. The rationale for studying the peculiarities of the influence of family interaction (the parents - children subsystem) on the further development of civic competence of young people is provided. Our basic assumption is understanding the role of a family as the one that determines not only the development of a child, but eventually the development of the whole society. The family environment is considered as a platform for developing attitudes, learning rules and norms, mastering interaction skills, which can promote / hinder the development of the child competence, and in the future the competent behavior of citizens in the society. The indicators for evaluation of the environment of family interaction are determined. The indicators, which will be used to assess the developmental potential of family interaction, are specified as follows: external and internal boundaries (existence and acceptance of interaction norms and rules, readiness to comply with them; responsible attitude to one's responsibilities; right to one's own opinion; right to participate in decisionmaking, readiness to voluntarily unite with others for a common goal); hierarchy (balance of dominance - subordination in interaction; ability to recognize the authority; control of decision-making; ability to subordinate one's intentions, actions to common interests); flexibility of norms and rules (variability of rules of interaction when the situation in the family (community) changes; openness of negotiations on norms and rules; possibility to change roles if necessary); cohesion ("We" image, ability to empathize, participate and understand the needs and interests of others, balance of autonomy - emotional connection).
Постановка наукової проблеми та іï значення. Невпинний процес суспільно-політичних трансформацій в Україні актуалізує проблематику громадянської компетентності молоді як найбільш прогресивної частки суспільства, від якої великою мірою залежить життя країни. Згідно зі слушною думкою Дж. Равена, «суспільство змінилося, а значить - і завдання, що постають перед нами, а відтак - i вимоги до компетентності, потрібні для вирішення цих завдань...» [11, с. 23]. Уявлення про межі своєї відповідальності як громадянина; готовність визначати межі прийнятного i дотримуватись правил взаємодії у суспільстві; відповідальне ставлення до власних громадянських обов'язків; віра у здатність впливати та знання механізмів впливу, переживання причетності до проблем спільнот(и) і т.д. - усе це великою мірою визначає поведінку громадянина. Сьогодні на часі нова концепція ролі громадянина, за якої «гар- 
ний» громадянин бере активну участь у житті соціуму [11].

Тому нагальним завданням сьогодні $є$ визначення соціально-психологічних чинників, що сприяють формуванню готовності молодих людей до компетентної громадянської поведінки. Водночас відзначимо, що останнім часом соціально-психологічні дослідження, спрямовані на вивчення такого важливого чиннику розвитку громадянської компетентності, як взаємодія в сім'ї, в України не проводились, хоч актуальність таких досліджень $є$ безсумнівною. Актуальність дослідження особливостей впливу взаємодії в сім'ї (зокрема в підсистемі «батьки - діти») на подальший розвиток громадянської компетентності молоді зумовлюється усвідомленням ролі сім'і як такої, що визначає не лише розвиток дитини, а й врешті-решт - всього суспільства. Взаємодія дитини 3 батьками є першим досвідом відносин 3 оточуючим світом, що надалі визначає особливості поведінки з іншими людьми в громаді, суспільстві, державі.

Мета статті - обгрунтувати та описати показники дослідження взаємодії у сім'ї як чинника розвитку громадянської компетентності особистості, що зростає.

Аналіз останніх досліджень і публікацій, в яких започатковано розв'язання даної проблеми, показав, що громадянська компетентність по суті є синтезуючою, такою, що базується на опануванні ключовими, життєвими компетентностями, тому завдання створення умов для i становлення не вирішується засобами лише громадянської освіти. Значну роль у цьому процесі відіграє сім'я, де середовище сімейної взаємодії виступає як «навчальний простір» для набуття, опанування різноманітних компетентностей соціальної взаємодії [13].

Сім'я, виконуючи низку соціально-психологічних функцій, $\epsilon$ важливим компонентом соціальної структури суспільства, системою і формою соціальної спільності, в основі формування і розвитку якої - взаємодія. Це мала група, міні-модель суспільства, що має свій устрій, ієрархію, кордони, власні правила і норми, цінності, практики взаємодії, розподіл ролей i обов'язків, тощо. Підкреслимо, що сім'я - це соціальна система взаємодій. Тож особистість, що зростає, з дитинства занурена в соціальний світ сім’ї, де зміст і процеси іiї розвитку залежать від особливостей взаємодії 3 іншими членами родини, зокрема 3 батьками. У середовищі сім’і повсякчас вибудовується взаємодія між членами родини, що прямо, опосередковано чи неявно впливає (сприяє або, навпаки, утруднює або й унеможливлює) на розвиток компетентності дитини у т.ч. - й громадянської.
Докладний аналіз параметрів сім’ї як системи здійснили у своїх працях низка зарубіжних дослідників: А.Я. Варга [1], І.М. Нікольська та Е.Г. Ейдеміллер [16] та ін. Так, у межах структурної теорії сім’ї С. Мінухін виділяє параметри сімейної взаємодії, що визначають функціонування сім'ї як системи (згуртованість, ієрархія, кордони); а теорія сім'ї як системи М. Боуена окреслює емоційні процеси в сім’ї та гнучкість сімейної системи; тоді як теорія стосунків В.Н. М'ясіщєва, в основі якої - уявлення про особистість як систему стосунків зі світом, іншими людьми та із самою собою, дає змогу розглядати життєдіяльність членів сім'ї у взаємозв'язку їхньої комунікації та взаємостосунків [9]. Узагальнюючи дані вищезазначених досліджень та численні напрацювання психологів, психотерапевтів, було класифіковано параметри сімейної системи. Зокрема, Н.І. Оліфірович, Т.А. Зінкевич-Кузємкіна, Т.Ф. Велента [2; 9] визначають три основні групи параметрів: структурні (границі, альянси, ієрархію, згуртованість та гнучкість), процесуальні (комунікація, сімейні правила, сімейні міфи) та історичні параметри (стиль життя, очікування та потреби, що сформувалися під впливом минулого досвіду, способи функціонування, нерозв'язані конфлікти, тощо - усе, що набувається шляхом міжпоколінної передачі).

Ми зосередимо свою увагу на структурних параметрах сімейної системи [9], оскільки вони, на нашу думку, найбільшою мірою створюють підгрунтя для операціоналізації функціонування сімейного середовища як такого, що зумовлює розвиток громадянської компетентності дитини, що зростає у сім'ї. Ці параметри можуть виступати показниками оиінювання сімейної взаємодї̈. У нашому соціально-психологічному дослідженні це показники, за якими буде оцінюватись розвивальний потенціал сімейної взаємодї̈: зовнішні $\boldsymbol{i}$ внутрішні кордони (або «межсі», як їх ще називають); ісрархія; гнучкість норм і правил, згуртованість.

Виклад основного матеріалу дослідження. Розглядаючи сімейне середовище як соціальну систему стійких взаємодій та враховуючи специфіку взаємодій між членами родини, його можна охарактеризувати як: по-перше, сприятливе / перешкоджаюче для розвитку громадянської компетентності; по-друге, таке, що має свої особливі ресурси впливу на особистість громадянина, що зростає.

Метою нашого емпіричного дослідження $€$ визначення соціально-психологічних ресурсів середовища сімейної взаємодії як сприятливого для розвитку громадянської компетентності особистості, що зростає. 
Виходячи 3 мети нашого дослідження, ми сформулювали низку завдань, що сприятимуть досягненню кінцевої мети нашого дослідження. А саме:

1) виявити особливості взаємодії батьків i дітей, що сприяють (або перешкоджають) розвитку громадянської компетентності особистості, що зростає;

2) визначити характеристики середовища сімейної взаємодії, що зумовлюють розвиток громадянської компетентності дитини.

Для проведення емпіричного дослідження потрібно, передусім, розробити методичний інструментарій, що дозволить коректно й ефективно реалізувати визначені завдання та адекватні меті. А для цього, у свою чергу, необхідно виокремити показники та індикатори. Тож розглянемо та проаналізуємо показники оцінювання сімейної взаємодії та окреслимо їх у ракурсі розвивального потенціалу громадянської компетеності дитини.

Термін межа використовують для опису стосунків між сім'єю та соціальним оточенням, а також між різними підсистемами всередині сім'ї. Межі визначають структуру сім'ї та зміст ії життя. Межі системи або підсистеми являють собою правила, що визначають, хто $і$ як бере участь у взаємодіï [18], а значить - і стосунки між членами сім'ї. Внутрішні кордони визначають особливості взаємодії всередині системи (або підсистеми) сім'ї, а зовнішні-з іншими сімейними системами.

Психологічні межі (або кордони, як їх ще називають) - це межа, яка показує, де закінчується власне «Я» особистості і починається «не Я», або «Інший» (з його потребами, інтересами, бажаннями, емоціями, цінностями, планами, думками, поглядами, почуттями, ідеями, очікуваннями тощо).

Серед видів психологічних меж виділяють: так звані розумові, фізичні, емоційні і духовні кордони (Г. Клауд, Дж. Таунсед); тілесні, особисті, психологічні, соціальні, територіальні (Т. Леві, О. Лоуен, Л. Марчер, Д. Марчер, Ф. Перлз); інтимні, особистісні, соціально-дорадчі, публічні дистанції при комунікації (Холл). Виділяють також як окремий вид соціальні, або рольові межі, які пов'язані з роллю, з якою людина себе ідентифікує та 3 групою, до якої вона належить. Поняття меж соціальної системи розроблялось у рамках системної сімейної терапії, де визначались форми порушення кордонів (особистісних, підсистеми, системи в цілому) [5].

Усі різновиди особистих кордонів організовані за принципом відповідальності: «Якщо я чимось володію, то відповідаю за те, що знаходиться в межах моїх повноважень». Усвідомлення кордонів дозволяє привнести більше свободи в життя. Якщо людина знає, за що вона несе відповідальність, а за що - ні, то вона може більш вільно розпоряджатися своїм життям. Взяття на себе відповідальності за власне життя відкриває перед людиною множинність варіантів вибору. I навпаки, якщо людина не володіє своїм життям, то це обмежує іiї можливості (Г. Клауд) [6]. Людина відповідає перед іншими і за саму себе [6]. Наявність меж створює правила, які стосуються та врегульовують взаємодію людей. Тож позначення кордонів у взаємодії дозволяє іншій людині зрозуміти наявні правила, що діють, як-то кажуть, на вашій території. Важливо нагадати про те, що неможливо вимагати дотримання правил від дитини, якщо дорослі самі не дотримуються цих правил.

Для чого потрібні кордони в сімейній взаємодії? Передусім, діти потребують балансу між залежністю та автономністю; прив'язаністю і пізнанням світу. Діти $є$ допитливими, прагнуть вивчати і опановувати оточуючий світ, а для цього їм потрібна «надійна база», батьківський контроль, супровід у процесі пізнання світу, за межами материнських i батьківських обіймів. Виникає потреба у встановленні кордонів і обгрунтованих обмежень. Такі обмеження для дитини означають передусім упевненість і безпеку. Таким чином, межі встановлюються батьками для формування в дитини відчуття безпеки. Крім цього, дітям важливо передавати цінності. I ще один важливий момент: батьки також мають свої потреби, і діти повинні навчитися рахуватися $з$ цим $і$ узгоджувати власні потреби з нуждами інших людей (відповідно своєму віку і розвитку) [3].

Що стосується прав дитини у сім' 1 , то батьки, в цілому визнаючи наявність прав у дитини, самі часто порушують елементарні права своєї дитини - приміром, на володіння своїми речами або на вираження почуттів. У результаті дитина засвоює, що: можна порушувати кордони іншой людини, або що ї̈ власні кордони (права) не важливі; права на мою власність не $є$ однозначними, залежать від бажань інших осіб, і влада (батьки) чомусь на їх боці [14]. «Влада несправедлива», «влада не може бути справедливою», «мої права можна порушувати, це нормально». Як наслідок - такі діти виростають і продовжують жити, керуючись засвоєними в дитинстві правилами i сформованими у процесі взаємодії настановами і твердженнями. Подорослішавши, вони так і живуть, не розраховуючи ні на владу, ні на закон, із неприсвоєним правом на дотримання $\mathrm{i}$ втілення прав, готові погодитись із тим, що їхнє право можна порушувати, не брати до уваги, ігнорувати і т.д.

Суспільство ж складається із сімей, у яких зростають громадяни. Ці громадяни із часом голосуватимуть за владу - таку владу, яка, як то кажуть, за подобою до тієї, що виявлялася, зокрема, в бать- 
ківсько-дитячій взаємодії в їхній сімейній системі. Якщо дитина має досвід взаємодії, за якої батьківська влада виявлялась як справедлива і тверда, то i в дорослому житті вони будуть прагнути відтворити саме таку владу. Якщо дитина звикає бути жертвою, то буде виправдовувати насильників. Тому так важливо формувати зовсім інший досвід - досвід поваги до прав. Поваги до простих і доступних прав право на власні речі, власний простір, власні міркування, рішення і почуття. Якщо батьки будуть послідовними, то діти засвоять, що кожен має кордони і права. Вони отримають досвід влади, яка є справедливою і твердою. Саме таку владу вони прагнутимуть відтворити у своєму дорослому житті.

Крім цього, відзначимо, що наявність і дотримання батьками правил, дитина переживає як безпеку [14], що є важливим підгрунтям і умовою розвитку громадянської компетентності у сімейній взаємодії [13].

Г. Клауд, Дж. Таунсенд вважають, що ознакою «здорової» сім ‘, яка має потенціал для розвитку, є така, в якій психологічні межі існують, вони $€$ зрозумілими, означеними, прийнятими, тобто коли кожен член сімейної системи розуміє та визнає, що кожен із них:

1) є унікальним і цінним;

2) має право на свободу. Цінність свободи визнається. Існує співвідношення свободи і правил; свободи і відповідальності;

3) право на власну думку, на ii відмінність від думок інших людей, включаючи авторитетних значущих дорослих;

4) відповідає за власні дії, вчинки; виконання своїх обов' язків і зобов' язань;

5) готовий добровільно об'єднуватись 3 іншими заради спільної мети / суспільного блага (так звані духовні межі) [6].

Таким чином, кордони важливі та потрібні для: відчуття власної цілісності; присвоєння права на особистий простір; формування базової довіри до себе і світу та відчуття безпеки; відчуття власної автономії та незалежності; усвідомлення меж своєї відповідальності та їх окреслення у відносинах; балансування між «брати» i «давати» у взаємодії; розуміння своїх емоційних меж (не перейматися надто сильно проблемами інших людей; не дозволяти іншим «ранити» свої почуття); знаходження балансу між своїми та потребами інших; вибудовування здорової взаємодії з іншими людьми; безпечного зближення 3 людьми, не ранячи себе та інших; збереження себе у стосунках (не губити себе); управління дистанцією (зближення - віддалення) у спілкуванні; можливості бути членом групи і водночас плекати i цінувати свою індивідуальність, та ін. [6; 8].

Характеристиками «здорових» кордонів є гнучкість та здатність людини ними управляти. У будь- якій сімейній системі існують також альянси (свого роду об'єднання) між членами родини для виконання якої-небудь функції або для досягнення певної мети. У нормально функціонуючих сім'ях ці альянси непостійні й залежать від конкретної ситуації. Вони дозволяють членам сім’і відчувати особливу близькість, співпричетність.

У контексті завдань, що вирішуються в нашому дослідженні такого чинника розвитку громадянської компетентності молоді, як взаємодія в сім’і, ми виокремили індикатори сформованості кордонів:

- наявність і визнання норм і правил взаємодіï;

- дотримання правил співжиття (сфера взаємодії «Я - Інші»);

- межі прийнятного у взаємодії між членами спільноти;

- відповідальне ставлення щодо власних обов’язків перед Іншими (членами сім'ї, громади);

- право на власну думку;

- право на участь у прийнятті рішень;

- готовність добровільно об'єднуватись 3 іншими заради спільної мети.

Наступний показник оцінювання сімейної взаємодії, обраний нами, - ісрархія. К. Маданес визначає ієрархію як авторитет, домінування, владу приймати рішення або ступінь контролю чи впливу одного члена родини на інших [7; 17]. Контроль означає не тільки контроль над іншими - наприклад, над дітьми, - але також над прийняттям рішень у родині. Зміна ієрархії пов' язана зі зміною структури ролей та правил усередині сім’ї.

У руслі психотерапевтичного напряму розроблено уявлення про «здорову» (батьки визнаються головними в родині, приймають доленосні рішення, беруть на себе відповідальність) і «перевернуту» (дитина - головна; все в сім ї підпорядковано іï бажанням, вона керує батьками) ієрархію в сім’і.

Ставлення до влади як такої, як ми відзначали вище, формується в сім $\dddot{1}$, й зокрема у процесі встановлення батьками кордонів у взаємодії 3 дітьми. А завдяки владно-підвладним стосункам у сім $\dddot{1}$ діти набувають досвіду і підпорядкування, і домінування (лідерства, ініціативності) [2]. Саме особливості сімейної взаємодії можуть сприяти (або навпаки перешкоджати) розвитку здатності дитини визнавати авторитет влади, а також владу (і рішення) більшості, а також здатності дитини підпорядковувати власні бажання, наміри, дії, тощо спільним інтересам, що будуть благом для усієї сім’ї чи іншої спільноти, що важливо в контексті розвитку громадянської компетентності особистості.

Відзначимо, що надмірне нормування та ієрархізація взаємин, жорстке розподілення ролей, незмінність правил взаємодії може призвести до того, що система сімейної взаємодії стає ригід- 
ною, застарілою і такою, що не відповідає умовам, що повсякчас змінюються.

Відзначимо, що, з одного боку, чіткість і визначеність норм i правил $є$ важливими для встановлення кордонів у взаємодії, а відтак - i для побудови конструктивних стосунків. 3 іншого ж - занадто строго визначені, жорсткі і незмінні правила і норми взаємодії можуть породжувати відчуженість у взаємодії та провокувати формалізованість відносин.

Відповідно, у випадку необхідності пристосуватися до змін ситуації у сімейній системі такого типу виникає напруга у стосунках у зв'язку з тим, що необхідність «перебудови» викликає труднощі

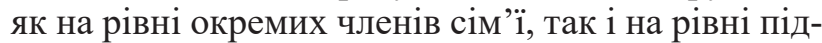
систем та усієї сімейної системи.

Таким чином, такий показник оцінювання розвивального потенціалу сімейної взаємодії, як «ієрархія», конкретизується нами через:

- баланс домінування - підпорядкування у взаємодії;

- здатність визнавати авторитет влади, а також владу (та рішення) більшості;

- контроль прийняття рішень;

- здатність підпорядковувати власні наміри, дії спільним (загальним) інтересам суспільного блага.

Наступний показник оцінювання сімейної взаємодії - згуртованість -може розглядатись як інтегративна характеристика функціонування сім’ї [12], яка включає ступінь емоційної близькості та прив'язаності між членами родини [1], та сформованість сімейної самосвідомості, когнітивним аспектом якої є образ «Ми», а афективним почуття «Ми» [4]. У разі максимально щільного емоційного зв' язку члени сім'ї максимально взаємозалежні, а в разі мінімального ступеню емоційного зв'язку - автономні та дистанційовані один від одного. Згуртованість значною мірою пов'язана із внутрішньосімейними границями, особливостями прийняття рішень, характером позасімейних зв 'язків членів сім 'ї. Наприклад, у випадку надмірної згуртованості, зовнішні границі сімейної системи часто виявляються занадто міцними, члени сім’ї найбільш зосереджені на внутрішньосімейних стосунках, одночасно границі між підсистемами можуть бути занадто прониклими.

Інтерес для нашого дослідження становить концепція «колективістичної ідентифікації» А.В. Петровського [10], згідно 3 якою в основі згуртованості лежать два соціально-психологічних механізми: 1) механізм емоційної ідентифікаиіï із сім'єю (за принципом «біль родини - мій біль») передбачає наявність у членів сім'ї високого ступеня розвитку емпатії, здатності до взаєморозуміння, співпереживання і співчуття. Ступінь згуртованості сім'ї значною мірою визначається перева- гою в ній відносин симпатії і позитивних емоцій, що дозволяє нейтралізувати емоційну напруженість, дистрес і фрустрацію; 2) механізм «спільності сімейної долі»: особистість пов'язує свої життєві плани, своє благополуччя та можливості особистісного саморозвитку саме із сім'єю. Відповідно, можна очікувати, що у випадку зростання згуртованості (звісно, окрім випадків із надмірним рівнем згуртованості) відбувається одночасне зростання здатності членів сім’ї до емпатії, співпереживання, співчуття, а також зростання загального сприятливого, позитивного фону спілкування у сім’і [12].

Д. Олсон, С. Мінухін виділяють чотири рівня згуртованості сімейних систем: 1) заплутана система (занадто високий рівень згуртованості), 2) роз 'єднана система (низький рівень згуртованості та лояльності сім'ї), 3) роздільна система (помірна згуртованість), 4) зв'язана система (високий ступінь емоційної близькості, лояльність у взаєминах і певна залежність членів сім’ї один від одного) $[15 ; 18]$. Члени зв'язаних і роздільних систем здатні поєднувати власну незалежність із емоційними зв'язками зі своїми сім'ями. Ці два типи сімейних систем є збалансованими. Стосунки в таких типах сімейних систем є більш конструктивними, менш напруженими (відсутні такі крайнощі, як надмірна емоційна близькість, повне поглинання стосунками, або ж, навпаки, надмірна дистантність, сильна емоційна віддаленість).

Підводячи підсумки, можна конкретизувати параметр згуртованості, за яким будемо оцінювати взаємодію у сімейному середовищі, так:

- образ «Ми» та почуття «Ми»,

- здатність до емпатії, співпереживання, співчуття, спів-причетності та розуміння потреб й інтересів Інших,

- баланс автономності - емоційної зв'язаності.

Сімейна гнучкість (ще один показник оцінки розвивального потенціалу сімейної взаємодії) характеристика того, наскільки гнучко або ригідно сімейна система здатна пристосовуватися, змінюватися за умови впливу стресорів на неї. Для діагностики гнучкості використовуються такі параметри, як: лідерство, контроль, дисципліна, правила та ролі в родині. Д. Олсон розробив циркулярну модель структури сім’ї [12; 15], яка містить 2 основні осі (згуртованість і гнучкість).

У теорії сімейних систем О. Кижаєва, А. Лідерс виділяють чотири типи залежно від рівня гнучкості: ригідна, хаотична, структурована, гнучка [5].

Ригідна система має дуже низьку гнучкість і адаптивність, тобто не здатна змінюватися та пристосовуватися до ситуації, що змінилася (народження, смерть членів родини, дорослішання дітей і відділення їх від родини, зміни в кар'єрі, місці проживання і т.д.). Система часто стає ригідною, 
коли вона надмірно ієрархізована або коли ролі занадто строго розподілені, а правила взаємодії залишаються незмінними. Відповідно, у випадку необхідності пристосовуватися до змін ситуації у сімейній системі такого типу виникає напруженість у стосунках у зв'язку з тим, що необхідність «перебудови» викликає складнощі як на рівні окремих членів сім’і, так і на рівні підсистем та усієї сімейної системи. Хаотична система характеризується дуже високим ступенем непередбачуваності, нестійкістю або обмеженістю керівництва й нестачею лідерства, імпульсивністю та необміркованістю рішень, неясністю ролей. Стосунки також можуть бути напруженими, адже у зв'язку з неузгодженістю та непередбачуваністю виникають розчарування через нездатність системи повноцінно функціонувати. Структурована система характеризується помірною гнучкістю, певним ступенем демократичного керівництва, стабільністю ролей та правил. Для гнучкої системи притаманний демократичний стиль керівництва, відкритість $i$ активність переговорів (до яких залучені діти), виражений розподіл ролей (з можливістю їх зміни в разі необхідності), співвіднесеність правил з віком членів родини [5; 12]. У разі збалансованості сімейної системи наявна менша напруженість та більша задоволеність стосунками (що значною мірою пов'язано із кращим функціонуванням сімейної системи завдяки балансу «стабільності» та «готовності до змін» у разі необхідності). Сімейні стосунки на рівні членів та підсистем функціональних, добре збалансованих сімейних систем є більш конструктивними та менш конфліктними [5; 12].

Таким чином, для ефективного функціонування сім’і потребують не лише балансу близькості-розмежованості, але також оптимального поєднання змін усередині родини зі здатністю зберігати свої характеристики стабільними.

Для нашого дослідження найбільш актуальним є розгляд гнучкості норм і правил взаємодіï, що конкретизуємо через такі індикатори, як:

- змінюваність правил взаємодії під час зміни ситуації у сім’ї (спільноті);

- відкритість і активність переговорів щодо норм і правил;

- можливість зміни ролей в разі необхідності;

- співвіднесеність правил із віком членів родини;

- співвідношення норм і правил та свободи.

Досвід особистості, що набувається в сім’ї, визначає внутрішню картину реальності, на основі якої вона сприймає й оцінює навколишній світ, соціальне середовище і діє в ньому.

У сім’ї (як малій групі, соціальній системі, локальному середовищі) вибудовується взаємодія між членами родини та спосіб життя, що може поширюватись й на інші соціальні середовища, спільноти, громади.

Таким чином, сім'ю розглядаємо як соціальну систему взаємодій, характеристики (специфіка) інтеракцій яких визначають сімейне середовище як сприятливе / несприятливе для розвитку особистості, що зростає загалом, й їі громадянської компетентності зокрема.

Отже, сімейне середовище із самого дитинства виступає майданчиком для засвоєння настанов та правил і норм, опанування навичок взаємодії, що може сприяти / перешкоджати розвитку компетентності особистості, а в подальшому - компетентної поведінки громадянина в суспільстві.

3'ясовано, що саме особливості взаємостосунків у батьківсько-дитячій підсистемі визначають вибудову системи життєвих цінностей особистості та громадянських чеснот, набуття нею досвіду дотримання правил і законів, виконання зобов'язань і норм, досвіду підпорядкування і автономності, відповідальності і свободи тощо.

\section{Висновки.}

Показниками для оцінювання середовища сімейної взаємодії визначено такі: зовнішні і внутрішні кордони; ієрархія; гнучкість норм і правил; згуртованість.

Конкретизовано індикатори для кожного показника, за яким буде оцінюватись розвивальний потенціал сімейної взаємодії:

- зовнішні і внутрішні кордони (наявність i визнання норм і правил взаємодії, готовність ї дотримуватись; співвіднесеність правил між членами родини; норми і правила співжиття (Я Інші); межі прийнятного у взаємодії між членами спільноти; відповідальне ставлення до власних обов'язків перед Іншими (членами сім’і, громади); усвідомлення меж відповідальності; право на власну думку; право на участь у прийнятті рішень; готовність добровільно об'єднуватись 3 іншими заради спільної мети);

- ієрархія (баланс домінування - підпорядкування у взаємодії; здатність визнавати авторитет влади, а також владу (та рішення) більшості; контроль прийняття рішень); здатність підпорядковувати власні наміри, дії спільним (загальним) інтересам суспільного блага;

- гнучкість норм і правил (змінюваність правил взаємодії під час зміни ситуації у сім ї (спільноті); відкритість і активність переговорів щодо норм і правил; можливість зміни ролей в разі необхідності; співвідношення норм і правил та свободи);

- згуртованість (образ «Ми» та почуття «Ми», здатність до емпатії, співпереживання, співчуття, спів-причетності та розуміння потреб й інтересів Інших, баланс автономності - емоційної зв'язаності). 


\section{ЛIТЕРАТУРА}

1. Варга А.Я. Системная семейная психотерапия. Санкт-Петербург : Речь, 2001. 144 с.

2. Васютинський В.О. Інтеракційна психологія влади : монографія. Київ, 2005. 492 с.

3. Гюру Э. Взаимодействие в семье. Самооценка у детей и подростков : книга для родителей. URL : https://psy.wikireading.ru/63541 (дата звернення: 17.09.2019 p.)

4. Карабанова О.А. Психология семейных отношений : учеб. пособие. Москва ; Самара : СИОКПП, 2001. $119 \mathrm{c}$.

5. Кижаева Е.Е., Лидерс А.Г. Системный подход в современной семейной психологи. Психолог в детском саду. 2004. № 3. С. 3-31.

6. Клауд Г., Таунсенд Дж. Барьеры / пер с англ. 7-е изд. Санкт-Петербург : Мирт, 2006. 382 с.

7. Маданес К. Стратегическая семейная психотерапия / пер. с англ. Т.В. Снегиревой. Москва : Независимая фирма «Класс», 1999. 272 с.

8. Нартова-Бочавер С.К. Новая версия опросника «Суверенность психологического пространства 2010». Психологический журнал. 2014. Т.35. № 3. С. 105-119.

9. Олифирович Н.И., Зинкевич-Куземкина Т.А., Велента Т.Ф. Психология семейных кризисов. Санкт-Петербург : Речь, 2006. 360 с.

10. Петровский А. В. Личность. Деятельность. Коллектив. Москва : Политиздат, 1982. 255 с.

11. Равен Дж. Компетентность в современном обществе: выявление, развитие и реализация. Москва : КОГИТО-ЦЕНТР, 2002. 396 с.

12. Сидоркіна М.Ю. Спільна художня творчість як чинник гармонізації сімейних стосунків : дис. ... канд. психол. наук : 19.00.05 / Ін-т соц. та політ. психології НАПН України. Київ, 2011. $216 \mathrm{c}$.

13. Скнар О.М. Взаємодія в сім'ї як чинник розвитку громадянської компетентності молоді: основні поняття дослідження. Проблеми політичної психології. 2019. Вип. 8. С. 74-88.

14. Хлебова В. От невежества к многообразию. Москва : ИОИ, 2016. 216 с.

15. Черников А.В. Системная семейная терапия: Интегративная модель диагностики. Москва : Класс, 2001. $208 \mathrm{c}$.

16. Эйдемиллер Э.Г., Добряков И.В., Никольская И.М. Семейный диагноз и семейная психотерапія. Санкт-Петербург : Речь, 2005. 336 с.

17. Madanes C. Strategic family therapy. San Francisco : Jossey-Bass, 1991. 272 p.

18. Minuchin S. Families and family therapy. Cambrige : Harvard University Press, 1974. 268 p.

\section{REFERENCES}

1. Varga, A.Ja. (2001) Sistemnaya semeynaya psikhoterapiya [Systemic family psychotherapy]. St. Petersburg: Rech. [in Russian]

2. Vasyutynskyy, V.O. (2005) Interaktsiyna psykholohiya vlady: monohrafiia [Interactive psychology of power]. Kyiv. [in Ukrainian]

3. Gyuru, E. (2019) Vzaimodeystviye v semye. Samootsenka u detey i podrostkov : kniga dlya roditeley [Family interaction. Self-Esteem in Children and Adolescents: A Book for Parents]. Retrieved from https://psy.wikireading.ru/63541

4. Karabanova, O. A. (2001) Psikhologiya semeynykh otnosheniy : uchebnoye posobiye [The psychology of family relationships]. Moscow; Samara: SIOKPP. [in Russian]

5. Kizhayeva, Ye. Ye., Liders, A. G. (2004) Sistemnyy podkhod v sovremennoy semeynoy psikhologi [A systematic approach in modern family psychology]. Psychologist in kindergarten, 3, 3-31. [in Russian]

6. Klaud, G., Taunsend, Dzh. (2006) Baryery [Barriers]. St. Petersburg: Mirt. [in Russian]

7. Madanes, K. (1999) Strategicheskaya semeynaya psikhoterapiya [Strategic family psychotherapy]. Moscow: Independent firm «Class». [in Russian]

8. Nartova-Bochaver, S. K. (2014) Novaya versiya oprosnika «Suverennost psikhologicheskogo prostranstva $-2010 »$ [New version of the questionnaire «Sovereignty of psychological space - 2010»]. Psychological journal, vol. 35, 3, 105-119. [in Russian]

9. Olifirovich, N.I., Zinkevich-Kuzemkina, T.A., Velenta, T. F. (2006) Psikhologiya semeynykh krizisov [Psychology of family crises]. St. Petersburg: Rech. (in Russ.)

10. Petrovskiy, A. V. (1982) Lichnost. Deyatelnost. Kollektiv [Personality. Activity. Collective]. Moscow: Politizdat. [in Russian]

11. Raven, Dzh. (2002) Kompetentnost v sovremennom obshchestve: vyyavleniye, razvitiye i realizatsiya [Competence in modern society: identification, development and implementation]. Moscow: Cogito-centre. [in Russian] 
12. Sydorkina, M.Yu. (2011) Spilna khudozhnya tvorchist yak chynnyk harmonizatsiyi simeynykh stosunkiv [Joint art creativity as a factor of harmonization of family relations]. Dissertation for the degree of candidate of psychological sciences. Kyiv. [in Ukrainian]

13. Sknar, O.M. (2019) Vzayemodiya v simyi yak chynnyk rozvytku hromadyanskoyi kompetentnosti molodi: osnovni ponyattya doslidzhennya [Interaction in the family as a factor in the development of civic competence of young people: the basic concepts of the study]. Problems of political psychology. Vol. 8, 74-88. [in Ukrainian]

14. Khlebova, V. (2016) Ot nevezhestva k mnogoobraziyu [From ignorance to diversity]. Moscow: IOI. [in Russian]

15. Chernikov, A.V. (2001) Sistemnaya semeynaya terapiya: Integrativnaya model diagnostiki [Systemic Family Therapy: An Integrative Diagnostic Model]. Moscow: Independent firm «Class». [in Russian]

16. Eydemiller, E.G., Dobryakov, I.V., Nikolskaya, I.M. (2005) Semeynyy diagnoz i semeynaya psikhoterapiya [Family diagnosis and family psychotherapy]. St. Petersburg: Rech. [in Russian]

17. Madanes, C. (1991) Strategic family therapy. San Francisco: Jossey-Bass. [in English]

18. Minuchin, S. (1974) Families and family therapy. Cambrige: Harvard University Press. [in English] 